Original Paper http://ajol.info/index.php/ijbcs http://indexmedicus.afro.who.int

\title{
Microbiological quality of some street foods in N'Djamena, Chad: case of sandwiches
}

\author{
Mayoré Atéba DJIBRINE ${ }^{1,3}$, Abdelsalam TIDJANI ${ }^{2 *}$, Bongo Nare NGANDOLO ${ }^{3}$, \\ Bessimbaye NADLAOU ${ }^{2}$ and Nicolas BARRO ${ }^{1}$
}

${ }^{I}$ Laboratoire de Biologie Moléculaire, d'Epidémiologie et de Surveillance des Bactéries et Virus transmissibles par les Aliments (LaBESTA) /Ecole Doctorale Sciences et Technologies, Université Ouaga I, Pr Joseph KIZERBO, 03 BP 7021 Ouagadougou 03, Burkina Faso.

${ }^{2}$ Laboratoire de Recherche en Science des Aliments et Nutrition (LARSAN), Faculté des Sciences de la Santé Humaine, Université de N'Djaména, BP 1117, N'Djaména, Tchad.

${ }^{3}$ Institut de Recherche en Élevage pour le Développement (IRED) de N'Djaména, BP. 433 N'Djaména, Tchad.

*Corresponding author,E-mail: abdelti@yahoo.fr

\begin{abstract}
Consumption of street food is growing rapidly in developing countries. Consequently, health problems associated with consumption of street foods exist everywhere and Chad is not an exception, but up to this day, there is limited scientific data on the microbiological quality and safety of foods sold in the street in various regions of the country. The aim of this study is to determine the microbiological quality of some street foods in N'Djamena, Chad: case of sandwiches. A total of 42 samples of sandwiches were collected. These samples were analyzed according to the standard methods of food microbiology. The analysis identified the different germs with respective compliance rates of $14.29 \%$ for thermotolerant coliforms, $54.76 \%$ for Coagulasepositive staphylococci, $47.62 \%$ for Escherichia coli and $19.05 \%$ for total mesophilic aerobic flora. The Salmonella compliance rate is $100 \%$. Also yeasts and molds were counted in some samples with an average of $0.80 \times 10^{6} \mathrm{CFU} / \mathrm{g}$. There is a significant correlation between MAF and Coagulase-positive staphylococci $(\mathrm{p}<0.05)$. The presence of these germs in general and mainly pathogens in sandwiches consumed in N'Djamena, Chad, represent a real public health problem which competent authorities should not neglect. (C) 2018 International Formulae Group. All rights reserved.
\end{abstract}

Keywords: sandwiches, quality, microorganisms, N'Djamena, Chad.

\section{INTRODUCTION}

The term "street food" means foods and beverages prepared and/or sold in streets and other public places for immediate consumption or consumption at a later time without further processing or preparation (Von holy et al., 2006). Street food plays an important socio-economic role: it provides a regular source of income for millions of low or unskilled men and women in developing countries (FAO, 2010). According to the Food and Agriculture Organization, there are about more than 2.5 billion people who eat street food everyday since street food is cheaper 
than a restaurant meal (FAO, 2001). However, these foods are also subjected to physical, chemical and microbiological contamination, affecting the safety of food products. Indeed, various food products in the streets are contaminated in general and particularly by enteric bacteria. Studies in Africa and around the world have shown that dairy products, local beverages, vegetables, cereal products, meat products, etc. are contaminated with pathogens (Mensah et al., 2002; Barro et al., 2005; Okareh et Erhahon, 2015; Camila, 2015). The pathogens involved in these foods include E. coli, Salmonella enterica, Staphylococcus aureus, coliforms, yeasts and molds at various levels (Bagré et al., 2014; Bsajo et al., 2014). These microorganisms are responsible for diarrhea often associated with fever, vomiting, abdominal cramps (Bonkoungou et al., 2013; Dembélé et al., 2015) mostly in children less than five years.

In Chad, studies have shown that most diarrhea diseases are due to coliforms and mostly E. coli, Salmonella enterica, Shigella, pathovars (Bessimbaye et al., 2013) but few studies have been conducted on the contamination of food with pathogenic bacteria. Several studies conducted on dairy and meat products in Chad showed contamination of these products by coliforms (fecal and total), and E. coli (Tidjani et al., 2007; Koussou et al., 2007). In recent years, food products such as sandwiches, rice with sauce (tomato and sorrel), the grilled meat and fried fish are increasingly consumed in educational institutions, markets, auto stations, industrial areas in mainly developing countries without the safety of these foods being guaranteed. The objective of this study was to evaluate the microbiological quality of street sandwiches (minced beef) sold and consumed in N'Djamena, Chad.

\section{MATERIALS AND METHODS}

\section{Study design and sampling}

Accounting for sales outlets in these districts was made in three parts. First counting was made in the morning from 06.30 to 09.30 , a second counting from 11.30 to $3.00 \mathrm{pm}$ and a third counting from 5.00 to $9.00 \mathrm{pm}$. In all we counted 2133 points sales outlets of which $58(2.72 \%)$ sellers of minced meat sandwich. Applying the $\mathrm{N}=\frac{t^{2} p(1-p)}{m^{2}}$ formula, the estimated sample size was approximately 41. However we took 42 samples. Sampling of food sold in the streets was carried out between October 2014 and October 2015 in eight (8) districts of N'Djamena (Figure 1). For this, 42 samples were collected between 10.30 and 2.00 p.m. Random sampling concerned essentially the chopped beef sandwich $(n=42)$. Samples of a quantity of $500 \mathrm{~g}$ were collected in sterile bags, transported to the laboratory at $4{ }^{\circ} \mathrm{C}$ and analyzed within a few hours.

\section{Surveys}

Out of the ten (10) districts of N'Djamena, eight (8) were chosen for the study. In the eight districts, special targeted sites were the markets, primary schools, secondary schools, higher and similar schools, industrial areas, stations (taxi journey), administrative areas, avenues and highways. First we counted these sales outlets and then a field trip followed to list the sellers who were present. Using a food identification sheet, all sandwich sale sites were identified and selected for sampling.

\section{Enumeration and characterization of microorganisms}

The preparation of the stock solution and serial dilutions were made according to standard ISO 7218 (ISO 2007). For the stock, $25 \mathrm{~g}$ of sample collected was homogenized into $225 \mathrm{ml}$ of buffered peptone water (Liofilchen, Italy). The successive dilutions up to $10^{-8}$ were made by adding $1 \mathrm{ml}$ of the dilution into $9 \mathrm{ml}$ of buffered peptone water.

For the enumeration of mesophilic aerobic flora, $0.1 \mathrm{ml}$ of the appropriate dilution was streaked into Plate Count Agar 
(Liofilchem, Italy) and plates were incubated at $30{ }^{\circ} \mathrm{C}$ for $72 \mathrm{~h}$ according to ISO 4833 standard.

For thermotolerant coliforms, 0.1 $\mathrm{ml}$ of the appropriate dilution was streaked into Violet Red Bile Lactose agar (Liofilchem, Italy) and plates were incubated at $44{ }^{\circ} \mathrm{C}$ for $24 \mathrm{~h}$ according to Standard NF V08 -060.

Enumeration of yeasts and molds was done by surface inoculation of $0.1 \mathrm{ml}$ of the appropriate dilution on Sabouraud agar with chloramphenicol (Liofilchem, Italy) and plates were incubated at $25{ }^{\circ} \mathrm{C}$ for 5 days according to ISO 7954 Standard.

Enumeration of $E$. coli was done by inoculating $0.1 \mathrm{ml}$ of the corresponding dilution deep into Tryptone Bile X (TBX) agar and plates were incubated at $44{ }^{\circ} \mathrm{C}$ for $24 \mathrm{~h}$ according to NF V08-053.

To search for positive staphylococci coagulase, the surface spreading technique of $0.1 \mathrm{ml}$ of the appropriate dilution on full Baird Parker agar made in duplicate was used. Then plates were incubated at $37{ }^{\circ} \mathrm{C}$ for $24 \mathrm{~h}$ according to V08-057-1 Standard. Then still V08-057-1 Standard, for identification, we marked on the bottom of the boxes the characteristic colonies (black or gray, shiny and convex surrounded by a clear halo) and re-incubated the same boxes at $37^{\circ} \mathrm{C}$ for $24 \mathrm{~h}$. The first confirmation phase consisted of taking three (3) characteristic colonies and submitting them to the catalase test. When the test is revealed negative, the result is given automatically. In the opposite case, a colony was removed and cultured in the Brain Heart Broth at $37{ }^{\circ} \mathrm{C}$ for 20 to $24 \mathrm{~h}$. The second confirmation phase consisted of the search for coagulase, that is to say $0.3 \mathrm{ml}$ of Rabbit Plasma was added to $0.1 \mathrm{ml}$ of culture. When the coagulase is negative, the result is given; otherwise, the result is expressed in the required formula.

For Salmonella enterica characterization, the ISO 6579/A1 method was used. To do this, $0.1 \mathrm{ml}$ of pre-enriched broth was homogenized into $10 \mathrm{ml}$ of
Rappaport-Vassiliadis Soja (RVS) broth and Muller-Kauffmann Tetra thionate-novobiocin and incubated respectively at $41.5{ }^{\circ} \mathrm{C}$ and 37 ${ }^{\circ} \mathrm{C}$ for $24 \mathrm{~h}$. For the selective isolation, Xylose Lysine Deoxycholate and Hektoen agars were used. Alleged Salmonella enterica colonies were confirmed by API 20E (bioMérieux, France).

\section{Data analysis}

The data obtained were keyboarded in Microsoft Excel 2010 and analyzed by XLSTAT 2009 software. In statistical data processing, for a significance level $\mathrm{p}<0.05$, the results obtained were considered significant.

\section{RESULTS}

\section{Characteristic of sandwiches sold on the streets of N'Djamena}

Survey results show that sandwiches sold on the streets of N'Djamena are highly seasoned with a lot of supplements such as vegetables. The main energy sources used in the preparation of these foods include in the majority wood, coal and in rare cases butane gas. As for the main utensils used in food handling, different sellers used hand and a ladle.

\section{Microbiological quality of sandwiches}

Microbiological analysis of the sandwich samples show that these sandwiches sold in the public squares of N'Djamena are contaminated in varying concentrations (Table 2 and Table 3).

The mesophilic total aerobic flora count results show that the sandwiches are heavily loaded, with the highest value being equal to $11.2 \times 10^{6} \mathrm{CFU} / \mathrm{g}$. The average load in FAMT of the 42 samples is equal to $6.3510^{6}$ $\mathrm{CFU} / \mathrm{g}$. The compliance rate of the samples compared to the MAF is $19.05 \%$.

Thermotolerant coliforms were detected in 36 of the 42 sandwich samples with the lowest compliance rate of $14.29 \%$. 
The high load observed was $3.0 \times 10^{6} \mathrm{CFU} / \mathrm{g}$. The average obtained was $0.65 \times 10^{6} \mathrm{CFU} / \mathrm{g}$.

The high E. coli load was $0.42 \times 10^{6}$ $\mathrm{CFU} / \mathrm{g}$ and the average sample size was $0.11 \times 10^{6} \mathrm{CFU} / \mathrm{g}$. The compliance rate was $47.62 \%$. The compliance rate for Salmonella was $100 \%$, that is, Salmonella was not detected in any sample.

Coagulase-positive staphylococci were found in 19 of the 42 samples. The highest load is $70 \times 10^{4} \mathrm{CFU} / \mathrm{g}$ and the lowest load is 0 . Out of the 42 samples, 23 are in accordance with the norms, conformity of $54.76 \%$.
Molds and yeasts are also detected in the 34 of 42 samples. The acceptability rate is $19.05 \%$.

The statistical analysis consisted in looking for a correlation between the different germs. When crossing MAF and thermotolerant coliforms, MAF and E. coli, thermotolerant coliforms and E. coli, no significant correlation is observed ( $\mathrm{p}>0.05)$. However, there is a significant correlation between MAF and Coagulase-positive staphylococci $(\mathrm{p}<0.05)$.

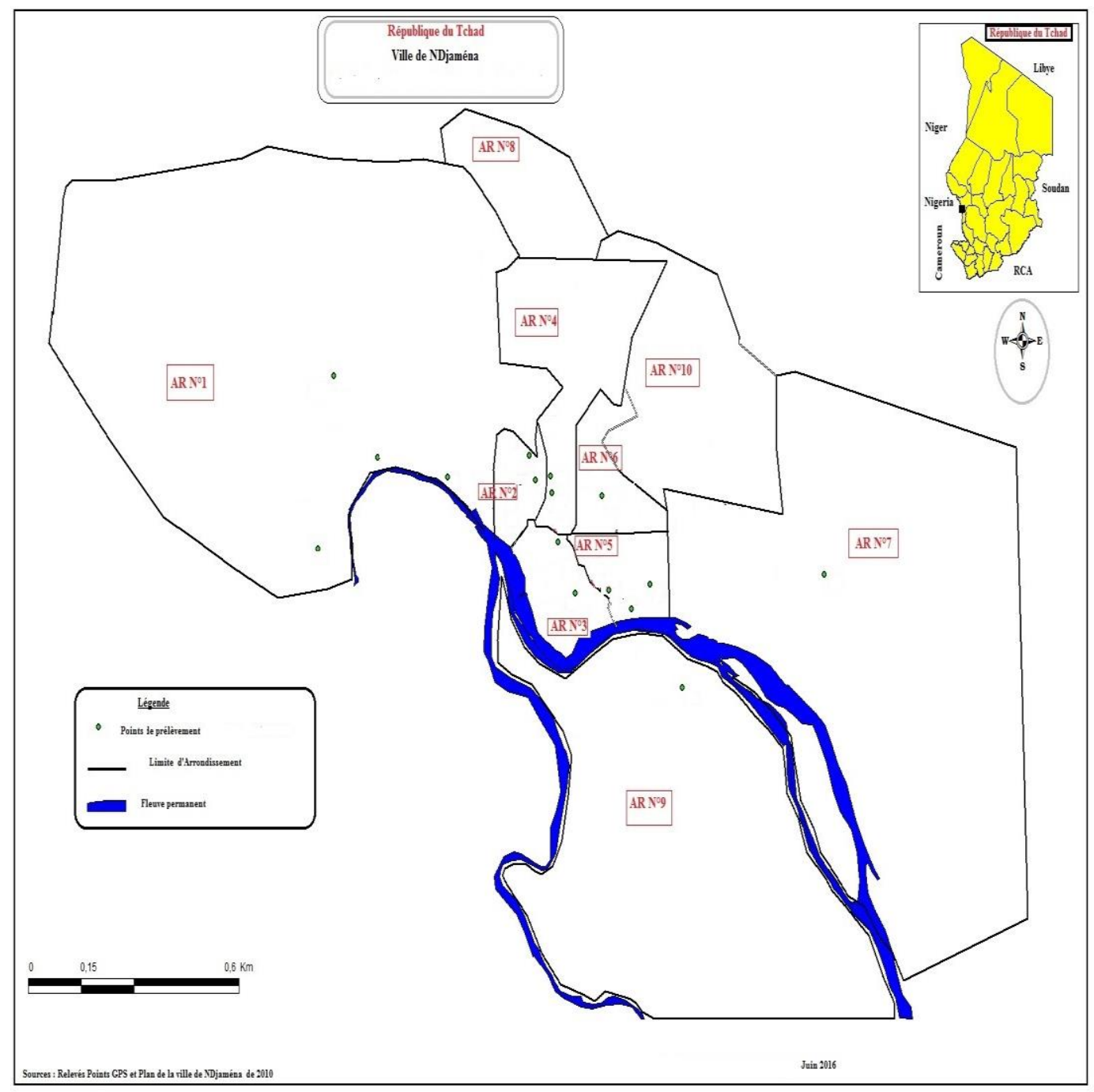

Figure 1: Sample location. 
Table 1: Characteristics of the types of food sold.

\begin{tabular}{ll}
\hline Characteristics & Description \\
\hline Composition & Bread loaded with cooked ground meat sauce with salad namely \\
& $\begin{array}{l}\text { tomatoes, potatoes, onions, mayonnaise, aroma oil and salt } \\
\text { Coal, bundle of firewood in rare cases of butane gas }\end{array}$ \\
Energy used & Fried bread and boiled the rest \\
Method of preparation & Bread grabbed by hand and loaded salad with a spoon \\
Utensils used to serve & Fixed-sellers are in the majority \\
Category sellers &
\end{tabular}

Table 2: Microbiological quality of sandwich sold in public places in N'Djamena.

\begin{tabular}{|c|c|c|c|c|c|c|}
\hline \multirow[b]{2}{*}{$\begin{array}{l}\text { Number of } \\
\text { sample }\end{array}$} & \multicolumn{6}{|c|}{ Parameter } \\
\hline & $\begin{array}{l}* \text { M. A.F. } \\
10^{6} \text { CFU } / g\end{array}$ & $\begin{array}{c}\text { Thermotolerant } \\
\text { coliforms } \\
10^{6} \mathrm{CFU} / \mathrm{g}\end{array}$ & $\begin{array}{c}\text { E. coli } \\
10^{6} \mathrm{CFU} / \mathrm{g}\end{array}$ & Salmonella & $\begin{array}{c}\text { Coagulase-positive } \\
\text { staphylococci } \\
10^{4} \mathrm{CFU} / \mathrm{g}\end{array}$ & $\begin{array}{c}\text { Yeasts and } \\
\text { molds } \\
10^{6} \mathrm{CFU} / \mathrm{g}\end{array}$ \\
\hline 1 & 2.00 & 3.00 & 0.30 & Absence & 19 & 0.80 \\
\hline 2 & 0.00 & 0.56 & 0.22 & Absence & 0 & 1.46 \\
\hline 3 & 0.00 & 1.02 & 0.28 & Absence & 0 & 1.72 \\
\hline 4 & 0.00 & 0.16 & 0.40 & Absence & 0 & 1.38 \\
\hline 5 & 0.00 & 1.28 & 0.34 & Absence & 0 & 0.85 \\
\hline 6 & 9.80 & 0.88 & 0.00 & Absence & 50 & 0.88 \\
\hline 7 & 2.00 & 0.86 & 0.40 & Absence & 0 & 1.84 \\
\hline 8 & 8.00 & 0.94 & 0.42 & Absence & 45 & 0.94 \\
\hline 9 & 7.10 & 1.02 & 0.00 & Absence & 30 & 0.70 \\
\hline 10 & 10.00 & 0.14 & 0.00 & Absence & 30 & 1.18 \\
\hline 11 & 10.00 & 0.66 & 0.32 & Absence & 23 & 0.66 \\
\hline 12 & 4.20 & 0.00 & 0.13 & Absence & 10 & 0.00 \\
\hline 13 & 11.20 & 0.78 & 0.00 & Absence & 30 & 1.78 \\
\hline 14 & 10.00 & 0.80 & 0.00 & Absence & 44 & 0.80 \\
\hline 15 & 11.20 & 0.54 & 0.30 & Absence & 45 & 0.64 \\
\hline 16 & 10.60 & 2.08 & 0.00 & Absence & 70 & 0.00 \\
\hline 17 & 10.00 & 0.90 & 0.00 & Absence & 57 & 0.90 \\
\hline 18 & 9.80 & 0.98 & 0.40 & Absence & 68 & 0.98 \\
\hline 19 & 9.60 & 0.31 & 0.00 & Absence & 54 & 1.36 \\
\hline 20 & 0.00 & 0.68 & 0.22 & Absence & 0 & 1.32 \\
\hline 21 & 0.00 & 0.64 & 0.00 & Absence & 0 & 0.12 \\
\hline 22 & 0.00 & 0.56 & 0.01 & Absence & 0 & 0.68 \\
\hline 23 & 0.00 & 0.46 & 0.00 & Absence & 0 & 0.00 \\
\hline 24 & 10.00 & 2.76 & 0.01 & Absence & 16 & 0.44 \\
\hline 25 & 9.00 & 1.64 & 0.00 & Absence & 13 & 0.21 \\
\hline 26 & 5.90 & 0.11 & 0.00 & Absence & 0 & 0.92 \\
\hline 27 & 9.60 & 0.88 & 0.03 & Absence & 0 & 1.36 \\
\hline 28 & 11.20 & 0.90 & 0.00 & Absence & 0 & 0.00 \\
\hline
\end{tabular}




\begin{tabular}{ccccccc}
\hline $\mathbf{2 9}$ & 9.80 & 0.76 & 0.01 & Absence & 15 & 1.54 \\
$\mathbf{3 0}$ & 4.00 & 0.20 & 0.00 & Absence & 0 & 0.00 \\
$\mathbf{3 1}$ & 6.20 & 0.09 & 0.01 & Absence & 0 & 1.08 \\
$\mathbf{3 2}$ & 6.80 & 0.12 & 0.00 & Absence & 0 & 1.19 \\
$\mathbf{3 3}$ & 7.60 & 0.10 & 0.25 & Absence & 0 & 0.70 \\
$\mathbf{3 4}$ & 6.80 & 0.10 & 0.00 & Absence & 0 & 0.98 \\
$\mathbf{3 5}$ & 10.00 & 0.11 & 0.00 & Absence & 8 & 0.80 \\
$\mathbf{3 6}$ & 8.60 & 0.00 & 0.21 & Absence & 0 & 0.00 \\
$\mathbf{3 7}$ & 6.80 & 0.00 & 0.00 & Absence & 0 & 1.06 \\
$\mathbf{3 8}$ & 1.40 & 0.00 & 0.00 & Absence & 0 & 0.00 \\
$\mathbf{3 9}$ & 6.60 & 0.00 & 0.32 & Absence & 3 & 0.76 \\
$\mathbf{4 0}$ & 5.40 & 0.00 & 0.00 & Absence & 0 & 0.00 \\
$\mathbf{4 1}$ & 11.20 & 0.10 & 0.00 & Absence & 0 & 0.80 \\
$\mathbf{4 2}$ & 3.40 & 0.11 & 0.18 & Absence & 0 & 1.00 \\
Average & $\mathbf{6 . 3 5}$ & $\mathbf{0 . 6 5}$ & $\mathbf{0 . 1 1}$ & Absence & $\mathbf{1 5}$ & $\mathbf{0 . 8 0}$ \\
Normes & $\mathbf{3 . 1 0}$ & $\mathbf{1 0}$ & $\mathbf{1 0}$ & Absence & $\mathbf{1 0}$ & $\mathbf{1 0}$ \\
AFNOR & & & & in 25g & & \\
\hline
\end{tabular}

* Mesophilic Aerobic Flora

Tableau 3: Global evaluation of flora determine from sandwich sold in public places in N'Djamena.

\begin{tabular}{|c|c|c|c|c|c|c|c|}
\hline \multirow[t]{3}{*}{ Germs } & \multirow{3}{*}{$\begin{array}{l}\text { Average } \\
\text { (UFC/g) }\end{array}$} & \multirow{3}{*}{$\begin{array}{c}\text { Extreme Values } \\
\text { (Number of } \\
\text { units) } \\
\text { [min/max] } \\
\text { (UFC/g) }\end{array}$} & \multirow{3}{*}{$\begin{array}{c}\mathbf{m} \\
(\mathrm{UFC} / \mathrm{g})\end{array}$} & \multirow{3}{*}{$\begin{array}{c}3 m^{*} \\
(\mathrm{UFC} / \mathrm{g})\end{array}$} & \multirow{2}{*}{\multicolumn{2}{|c|}{$\begin{array}{c}\text { Conformity } \\
\text { Number of units }\end{array}$}} & \multirow{3}{*}{$\begin{array}{c}\text { Conformity } \\
\%\end{array}$} \\
\hline & & & & & & & \\
\hline & & & & & True & Improper & \\
\hline M. A.F. & $6.35 \times 10^{6}$ & $0-11.2 \times 10^{6}$ & $3 \times 10^{5}$ & $9 \times 10^{5}$ & 8 & 34 & 19.05 \\
\hline $\begin{array}{l}\text { Thermotolerant } \\
\text { coliforms }\end{array}$ & $0.65 \times 10^{6}$ & $0-3.00 \times 10^{6}$ & 10 & 30 & 6 & 36 & 14.29 \\
\hline E. coli & $0.11 \times 10^{6}$ & $0-0.42 \times 10^{6}$ & 10 & 30 & 20 & 22 & 47.62 \\
\hline Salmonella & 0 & 0 & $\begin{array}{l}\text { Absence } \\
\text { in } 25 \mathrm{~g}\end{array}$ & NA & 42 & 0 & 100 \\
\hline $\begin{array}{l}\text { Coagulase- } \\
\text { positive } \\
\text { staphylococci }\end{array}$ & $0.15 \times 10^{6}$ & $0-0.70 \times 10^{6}$ & $10^{2}$ & $3 \times 10^{2}$ & 23 & 19 & 54.76 \\
\hline Yeasts and molds & $0.80 \times 10^{6}$ & $0-1.84 \times 10^{6}$ & $\mathrm{NC}$ & $\mathrm{NC}$ & $\mathrm{NC}$ & $\mathrm{NC}$ & $\mathrm{NC}$ \\
\hline
\end{tabular}

m: The standard of the French Standardization Association (AFNOR). NA = Not Applicable. NC = Not considered.

3m*: Acceptability threshold for the solid enumeration method with analytical tolerance. 


\section{DISCUSSION}

Total aerobic plate count was reported in the majority of samples analyzed. Out of the 42 samples analyzed, only 8 samples were largely below the acceptability threshold, that is a compliance rate of $19.05 \%$. These values obtained were above the standard criteria defined by AFNOR. Several studies in African countries have shown values as high in the types of foods such as meat, sandwiches, rice tomato sauce (Barro et al., 2002; Cohen et al., 2006; Baba-Moussa et al., 2006; Uzeh et al., 2006; Tidjani et al., 2006; Ilboudo et al., 2009; El Marnissi et al., 2012). The high level of contamination of the samples by bacteria responsible for spoilage and indicator of total unhealthiness could be explained by the lack of observation of the good manufacturing practices and also the lack of cold chain, holding temperatures inappropriate given the few recommended storage hardware. The sale of food in public places in N'Djaména is largely carried out by men and women without specific qualifications. These street food producers have no training in good manufacturing practice and do not perceive the influence of their preparation on the microbiological quality of food available to consumers. Although the strong presence of total aerobic plate count does not inevitably imply the presence of pathogenic bacteria, it could mean that the ecology of the food is possibly conducive to development of pathogenic bacteria.

Thermotolerant coliforms and Escherichia coli were also identified in the sandwiches. High loads were $3.00 \times 10^{6}$ and $0.42 \times 10^{6}$ for thermotolerant coliforms and Escherichia coli, respectively. The compliance rate is respectively $14.29 \%$ and $47.62 \%$ for thermotolerant coliforms and Escherichia coli. These samples analyzed showed charges at least hundredfold higher than the limits recommended by the standard. Similar studies in Morocco, Benin, Burkina Faso, South Africa, Nigeria, Ghana and Jordan have also found levels of thermotolerant coliforms and $E$. coli in meat, sandwiches or pasta that may pose a health risk to the consumers (Mensah et al., 2002; Barro et al., 2002; Cohen et al., 2006; BabaMoussa et al., 2006; Tidjani et al., 2006; Christion et al., 2007; Ahoyo et al., 2012; Laila et al., 2014). In this study, these results could be explained by the lack of hygiene practices and especially the control of hardware device disinfection because contamination could come from the same work tools and work surface (Chen et al., 2001; Christion et al., 2007; Barro et al., 2007). We can also justify the charges raise by the lack of observation of the decontamination protocol generally recommended by HACCP measures. The food handlers do not usually have a device to disinfect their hands after toilet. It is a behavior that could justify the presence of these bacteria generally indicative of fecal contamination. Moreover, most of the street sold foods were prepared, cooked and stored at the sellers' homes prior to selling. At the selling site, the required temperature preventing multiplication of pathogens in the foods may not be observed thus, resulting in contamination.

Coagulase-positive staphylococci was present in $45.24 \%$ of samples, all this proportion of samples was unsatisfactory. These foods analyzed are excessively loaded with Coagulase-positive staphylococci, it is sufficient proof of lack of personal hygiene. Our results are similar to other studies in the same direction (Mensah et al., 2002; Barro et al., 2002; Christison et al., 2007; Ahoyo et al., 2010; Sad1k et al., 2014; Ashraf et al., 2014; Kassé et al., 2014; Ogunyemi et al., 2015; Soncy et al., 2015). These results could be explained by the fact that most of the food handlers do not use hair net, gloves and other protective gear when preparing and serving. Sellers usually take money with the same hand used to serve food. Without considering washing of hands after, these sellers eventually prepare the next foods to be served thus, adding up to food contamination. However, satisfactory results have been found in similar studies especially in corn dough, grilled meat and orange juice (Baba-Moussa 
et al., 2006). This result can be explained by the level of good hygiene practices.

The ubiquity of molds and yeasts to loads greater than the standards in sandwiches is sufficient proof that food is kept long under unfavorable conditions. Some studies have shown the presence of molds and yeasts in street foods such as «kebab», grilled meat, vegetables and milk and its derivatives (Christison et al., 2007; El Marnissi et al., 2012). Unlike our results, some studies have noted the total absence of molds and yeasts in foods (El Marnissi et al., 2012). Manipulators' hands and work tools can also be responsible for these infections (Christison et al., 2007).

In general the total number of the foods analyzed indicates the absence of Salmonella. This result is similar to those of many studies of street food (Baba-Moussa, 2006; El Marnissi et al., 2012 ; Abdalhamid et al., 2013). This lack is not a guarantee of the quality of food sold and does not totally exclude the absence of Salmonella because the effect of the competition can also prevent the presence of Salmonella. In food, Salmonella is a highly dangerous element for the health of the consumers. Salmonella is the leading cause of foodborne illness and the factors favoring its presence is usually the environment and equipment (Belomaria, et al., 2007).

\section{Conclusion}

It is clear from this study that the samples analyzed sandwiches have varying bacterial loads whose values sometimes exceed the acceptability thresholds. Although street food is a capital socioeconomic and nutritional need, the presence of certain germs in these foods shows that sellers do not observe good hygiene practices during preparation and sale. Indeed mishandling and exposure to the weather of these foods are responsible for the fact that these foods are sometimes poisoned. Microbiological contamination of these foods is a result of several factors, among which non-compliance with good hygiene practices by sellers and especially the conditions of sale in often very unhealthy environments.

Considering the gravity of the situation, it is urgent to undertake immediate permanent and continuous sensitization of sellers and consumers on good hygiene practices. It should also enhance the skills of health policy and organize cooperative sellers to enable them to move towards the professionalization of their business.

\section{COMPETING INTERESTS}

The authors have not declared any competing interests.

\section{AUTHORS' CONTRIBUTIONS}

This manuscript is the presentation of part of doctoral research of Mayoré Atéba Djibrine, supervised by Nicolas BARRO and monitored by Abdelsalam TIDJANI. Bongo Nare NGANDOLO and Bessimbaye Nadlaou provided guidance in laboratory analysis and data management.

\section{ACKNOWLEDGEMENTS}

We would like to warmly thank the Research Project and Support for Street Food Safety ("PRASAR"), who financially supported us throughout the laboratory phase. We are as well indebted to the site of the Research Institute of Livestock Development ("IRED") without whose technical platform we could not have attained this more acceptable form of our research.

\section{REFERENCES}

Abdalhamid SA, Farj AA, Ali AB. 2013. Bacterial Contamination of Ready to Eat Foods (Shawerma Sandwiches) in Misurata City, Libya. $2^{\text {nd }}$ International Conference on Environment, Agriculture and Food Sciences (ICEAFS'2013) May 6-7, Kuala Lumpur (Malaysia).

Ahoyo TA, Ahissou H, Kounon F, Aminou T, Dramane K. 2010. Etude de la qualité bactériologique des aliments vendus sur le campus de l'Université d'Abomey Calavi au Bénin. Int. J. Biol. Chem. Sci., 4(4): 1083-1092.

Ashraf MAEM. 2014. Microbiological Quality of Ready-to-Eat Liver Sandwiches (Kibda). Global Veterinaria, 13(6): 1097-1102, 2014.

Baba-Moussa L, Bokossa YI, Baba-Moussa F, Ahissou H, Adeoti Z, Yehouenou B, Mamadou A, Toukourou F, Sanni A. 
2006. Etudes des possibilités de contamination des aliments de rue au Benin: Cas de la ville de cotonou. $J$. Rech. Sci. Univ. Lomé (Togo), série A, 8(2) : 149-156.

Bagré TS, Kagambèga A, Bawa IH, Bsadjo Tchamba G, Dembélé R, Zongo C, Savadogo A, Aggad H, Traoré AS, Barro N. 2014. Antibiotic susceptibility of Escherichia coli and Salmonella strains isolated from raw and curds milk consumed in Ouagadougou and Ziniaré, Burkina Faso. Afri. J. Microbio. R., 8: 1012-1016.

Barro N, Gamene AA, Itsiembou Y, Sawadogo A, Nikiema AP, Ouattara CAT, De Souza CA, Traoré AS. 2007. Street-vended Foods Improvement: Contamination Mechanisms and Application of Food Safety Objective Strategy: critical review. Pakistan Journal of Nutrition, 6(1): 01-10.

Barro N, Nikiéma PA, Ouattara CAT, Traoré AS. 2002. Evaluation de l'hygiène, de la qualité microbiologique de quelques aliments de rue et caractéristiques des consommateurs dans les villes de Ouagadougou et de Bobo Dioulasso (Burkina Faso). Sci. Tech. Sci. Santé, 25: 7-21.

Barro N, Sangaré L, Tahita MC, Ouattara CAT, Traoré AS. 2005. Les principaux agents du péril fécal identifiés dans les aliments de rue et ceux des cantines du Burkina Faso et ailleurs et les risques de maladies associées. Colloque Régional scientifique et Pédagogique: Maîtrise de procédés en vue d'améliorer la qualité et la sécurité des aliments, utilisation des OGM, analyses des risques en Agroalimentaires. Du 8 au 10 novembre 2005 à Ouagadougou UO/AUF/GP3A/CIDEFA.

Belomaria M, Ahami AOT, Aboussaleh Y, Elbouhali B, Cherrah Y, Soulaymani A. 2007. Origine environnementale des intoxications alimentaires collectives au Maroc: Cas de la région du Gharb Chrarda Bni Hssen. Antropo, 14 : 83-88. www.didac.ehu.es/antropo.

Bessimbaye N, Tidjani A, Moussa AM, Brahim BO, Mbanga D, Ndoutamia G,
Sangaré L, Barro N, Traoré AS. 2013. Gastroenteritis with Escherichia coli in pediatric hospital in N'Djamena-Tchad. J. Appl. Biol. Biotechnol., 1(2): 13-17.

Bonkoungou I, Haukka K, Österblad M, Hakanen AJ, Traoré AS, Barro N, Siitonen A. 2013. Bacterial and viral etiology of childhood diarrhea in Ouagadougou, Burkina Faso. BMC Pediatrics, 13: 1-6.

Bsadjo Tchamba G, Bawa IH, Nzouankeu A, Bagré TS, Dembélé R, Bonkoungou IJO, Zongo C, Savadogo A, Traoré AS, Barro N. 2014. Occurrence and antimicrobial susceptibility of Escherichia coli and Salmonella spp. isolated from "zoomkoom" beverage and ice in Ouagadougou, Burkina Faso. Afri. $J$. Microbio. R. 8: 3243-3249.

Camila BA. 2015. Bacteriological examination of ready-to-eat foods (RTE) products of Teheran province. Iran. Adv. F. S. T., 3(7): 328-331.

Chen YH, Jackson KM, Chea FP, Schaffner DW. 2001. Quantification and variability analysis of bacterial cross-contamination rates in common food service tasks. Journal of Food Protection, 64: 72-80.

Christison CA, Lindsay D, von Holy A. 2007. Microbiological survey of ready-to-eat foods and associated preparation surfaces in retail delicatessens, Johannesburg. South Afri. F. Cont., 10: 1016.

Cohen N, Ennaji H, Hassar M, Karib H. 2006. The bacterial quality of red meat and offal in Casablanca (Morocco). Mol. Nutr. Food Res., 50: 557-562.

Dembélé R, Bonkoungou IJO, Konaté A, Tchamba GB, Bawa HI, Bako E, Bagré TS, Kagambèga A, Zongo C, Traoré AS, Barro N. 2015. Serotyping and antimicrobial resistance of enteropathogenic Escherichia coli $\mathrm{O} 157$ isolated from children under five years of age with diarrhea in rural Burkina Faso. Afri. J. Microbio. R., 9(14) : 10531059.

El Marnissi B, Bennani L, El oulali lalami A, Aabouch M, Belkhou R. 2012. Contribution à l'étude de la qualité microbiologique de denrées alimentaires 
commercialisées à Fès-Boulemane. Rev. Microbiol. Ind. San et Environn., 6(1): 98-117.

FAO. 2010. The State of Food Insecurity in the World. FAO. Available from http://www.fao.org/docrep/013/i1683e/i1 683e.pdf (Accessed on November 26, 2014)

FAO. 2001. Alimentation de rue. FAO.

Ilboudo AJ, Savadogo A, Barro N, Ouedraogo M, Traore AS. 2009. Qualité hygiénique de la viande utilisée en restauration collective dans trois restaurants universitaires de Ouagadougou (Burkina Faso). Cahiers Santé, 19(4) : 195-199.

Kassé M, Cissé M, Touré A, Ducamp-Collin M-N, Guissé A. 2014. Qualité microbiologique des tranches de mangues (Mangifera indica L.) vendues à Dakar (Sénégal). Int. J. Biol. Chem. Sci., 8(4): 1611-1619.

Koussou MO, Grimaud P, Mopate LY. 2007. Evaluation de la qualité physicochimique et hygiénique du lait de brousse et des produits locaux commercialisés dans les bars laitiers de N'Djamena au Tchad. Elev. Mèd. Vèt. Pays Trop., 60: 45-49.

Laila N, Fatina AAD, Raymond B. 2014. Foodborne bacterial pathogens recovered from contaminated shawarma meat in northern Jordan. J Infect Dev Ctries, 8(11): $1407-1414 . \quad$ DOI: 10.3855/jidc. 4368 .

Mensah P, Yeboah-Manu D, Owusu-Darko K, Ablordey A. 2002. Street foods in Accra, Ghana: how safe are they? Bul. WHO., 80: $546-554$.

Ogunyemi AK, Buraimoh OM, Onuorah NO, Ezeugwu SMC, Odetunde SK, Olumuyiwa EO. 2015. Bacteria associated with contamination of readyto-eat (RTE) cooked rice in Lagos-
Nigeria. Int. J. Biol. Chem. Sci., 9(5): 2324-2333.

Okareh OT, Erhahon OO. 2015. Microbiological Assessment of Food and Hand-Swabs Samples of School Food Vendors in Benin City, Nigeria. F. Pu. H., 5(1): 23-28.

Sadık B, Devrim B, Ergun ÖG, Filiz K, Pelin K. 2014. Microbiological evaluation of ready-to-eat sandwiches served near hospitals and schools. Ankara Üniv Vet Fak Derg, 61 : 193-198.

Soncy K, Anani K, Djeri B, Adjrah Y, Eklu MM, Karou DS, Ameyapoh Y, De Souza C. 2015. Hygienic quality of ready-to-eat salads sold in the street and a modern restaurant in Lomé, TOGO. Int. J. Biol. Chem. Sci., 9(4): 2001-2010.

Tidjani A, Agassounon Djikpo Tchibozo M, Ameyapoh Y, Toukourou F, De Souza C. 2007. Essais de conservation des viandes séchées «kilichi» commercialisées au Tchad. Microbiol. Hyg. Alim., 20 : 27-34.

Tidjani A, Brahim BO, Ameyapoh B, Soncy M, Anani T, De Souza C. 2006. Appréciation de la qualité hygiénique des grillades de bœuf vendues à Lomé Togo. Ann. Univ. N’Djaména. Sér. C, Sci. Exactes Appl., 82-88.

Uzeh RE, Ohenhen RE, Adeniji OO. 2006. Bacterial Contamination of Tsire-Suya, a Nigerian Meat Product. Pakis. J. Nutri., 5(5): 458-460.

Von Holy A, Makhoane FM. 2006. Improving street food vending in South Africa: Achievements and lessons learned. Int. J. F. Microbio., 111 : 89-92. 